\title{
Characteristics of Bodies and Ethnicity c. 900-1200
}

\section{Claire Weeda*}

Examining synchronic and diachronic discourses of the body in relation to groups sheds light on concepts of 'ethnicity from an emic perspective. From the tenth century, monks, first in Spain and later in North-Western Europe, began to compile lists of ethnic characteristics, summing up the virtues and vices of peoples. By the twelfth century, such enumerations of ethnic diversity featured in textbooks of rhetoric, collections of proverbs, and in poetry and prose. The ontology of ethnic characteristics likewise transformed from the religious-ethical to the medical. Early medieval monks catalogued the virtues and vices of groups loosely arranged according to an Evagrian or Gregorian ethical system of seven or eight cardinal sins and virtues, expounding the function of groups` moral dispositions, which were, in the eschatological history of salvation in both the past and the present, subject to free will. However, from the twelfth century, under the impact of Galenic humoral theory, students of the liberal arts began to attribute ethnic characteristics on biological grounds, referring in particular to the heredity influence of climate. In the same period, ethnic groups were now considered as entities dwelling in bounded territories that bore the stamp of their name, sometimes envisaged as a body politic. As such, the ethnotype, and its ruler, could stand as a pars pro toto for the 'nation'.

Keywords: Central Middle Ages; ethnic character; virtues and vices; eschatology; rhetoric; Galenic humours; body politic

From the tenth century, first Asturian monks, followed slightly later by members of the religious orders stretching from Anglo-Saxon England and Normandy to the present-day Swiss Alps, undertook the compilation of lists cataloguing the virtues and vices of ethnic-religious groups. These might speak of, for instance, the envy of the Jews, the pride of the Romans or the ferocity of the Franks ${ }^{1}$. These early ethnic lists feature in manuscripts often containing encyclopaedic-topographical knowledge or computus material, and in some cases alongside listings of the region's characteristic products. ${ }^{2}$ From the late eleventh century, these catalogues, sometimes jotted down in the margins or on the front or back folio cover of manuscripts, transform into a marriage of traditional knowledge and contemporary obser-

* Correspondence details: Claire Weeda, Institute for History, P.O. Box 9515, 2300 RA Leiden, The Netherlands. Email: c.v.weeda@hum.leidenuniv.nl.

1 The oldest known list, beginning Sapientia Graecorum, Fortia Gothorum, can be found in the Codex Aemilianensis (Madrid, Biblioteca Real Academia MS 39), dated to about 950. It was afterwards copied into other Spanish manuscripts. It is printed in Chroniques Asturiennes, ed. Bonnaz, 11, and in Chronica minora saec. iv. v. vi. vii, ed. Mommsen, 389-390. In the eleventh century, a list beginning Invidia Iudeorum, Perfidia Persarum was inserted in the Codex Matritensis v 191, and also recorded in Bern MS 48 f. 1 and in Rouen, Bibliothèque Municipale MS 1406 (Y.41) Av-Bv. It is printed in Burnam, Miscellanea Hispanica, 169; cf. Omont, Vices et vertus des différents peuples, 580-581.

2 For example the list beginning with Polla de Narbona, Vini de Bilasç, in the tenth-century Codex Aemilianensis, Madrid Biblioteca Real Academia MS 39, printed in Chroniques Asturiennes, ed. Bonnaz, 8-13. 
vation. Lists of ethnic affects make their way into rhetorical textbooks and poetry produced at cathedral schools and universities, as well as in letters and collections of proverbs, in some cases even culminating in ethnic slanging matches attacking the Other. Expanding the catalogue 'Envy of the Jews, Perfidy of the Persians', English manuscripts thus now speak of the rapacity of the Normans or the cunning of the Saracens. ${ }^{3}$ By this period, the context and underlying ontology of catalogues of ethnic character had transformed from the monastic religious-eschatological to the contemporary urban world of learning, where students practiced literary embellishment and satire, and were informed by newfangled ideas about the humoral make-up of ethnic groups based on Galenic medicine. ${ }^{4}$ Although the catalogues of ethnic groups still often remained an enumeration of peoples arranged under the umbrella of Christendom, with Rome as its pinnacle, derision, satire and literary forms such as the priamel thus put their stamp on catalogues of ethnic character in the later Middle Ages. ${ }^{5}$

In the past, such specimens of the belief that ethnic groups had shared characteristics were downplayed as mere utterances of ethnic animosity, or, on the other side of the spectrum, as evidence that a national consciousness or even a sense of 'nationalism ' existed in the later Middle Ages. ${ }^{6}$ In accordance with post-Second World War historiographical trends, scholars have looked towards burgeoning bureaucratization and state centralization as explanatory frameworks for the rrise of the nation-stater. ${ }^{7}$ In addition, departing from sociological-anthropological perspectives, some have emphasized the relational aspect of ethnicity, referring to the increase in mobility and international contacts ${ }^{8}$ some pointed to the expansion of Europe's frontiers and colonization rhetoric; ${ }^{9}$ or attempted to engage with a comprehensive emic approach identifying the building blocks relevant to ethnicity and their interplay in the period at hand, such as narratives of descent, language, shared customs, and laws. ${ }^{10}$ Above all, these multifarious approaches and interpretations indicate the complexity of researching the what, when and why of nationhood, as scholars were and are doomed to

3 For instance in Corpus Christi MS 139. f. 166v., probably dating to the late twelfth century, and Corpus Christi MS 139 f. 179 r. of the thirteenth century, printed in Wright and Halliwell, Reliquiae Antiquae, vol. 1, 127.

4 Eliav-Feldon et al., Origins of Racism in the West, for the impact of Galenic medicine on thinking about ethnicity from the twelfth century. For the rise of stereotyping in this period and the role of university education, see Weeda, Ethnic Stereotyping in Twelfth-Century Paris.

5 Many examples presented in Kot, Old International Insults and Praises.

6 For ethnic stereotypes as utterances of animosity and xenophobia, see Brühl, Deutschland, Frankreich, 275. Examples of viewing the application of ethnic stereotypes as evidence of a sense of nationalism, for instance in Koht, Dawn of Nationalism in Europe; Coulton, Nationalism in the Middle Ages, Tipton, Nationalism in the Middle Ages; cf. also Mohr, Zur Frage des Nationalismus im Mittelalter. Kirn, Frühzeit des Nationalgefühls, offers a wealth of sources but these are interpreted, in Nazi Germany, within the context of demonstrating the 'centuries-old ethnic consciousness of the German and French peoples. Recently, Hirschi, Origins of Nationalism, argued for the impact of the ancient concept of the imperium on the rise of nationalism in the late Middle Ages. See Weeda, Ethnic Identification and Stereotypes for an extensive bibliography.

7 For instance, Guenée, States and Rulers in Later Medieval Europe; Clanchy, England and its Rulers; Ehlers, Entstehung des deutschen Reiches.

8 Schmugge, Über »nationale«Vorurteile im Mittelalter.

9 Bartlett, Making of Europe.

10 Davies, Peoples of Britain and Ireland 1100-140o I; Davies, Peoples of Britain and Ireland 1100-1400 II; Davies, Peoples of Britain and Ireland 1100-1400 III and Davies, Peoples of Britain and Ireland 1100-1400 IV. Bartlett, Medieval and Modern Concepts of Race and Ethnicity; Blaicher, Zur Entstehung und Verbreitung nationaler Stereotypen; Ehlers, Elemente mittelalterlicher Nationsbildung in Frankreich. 
work with categories and concepts shaped by modern phenomena and are thus exposed to the dangers of subsequently identifying similar building blocks of ethnicity in social group formation in medieval times. Attempting to pinpoint what a nation was, and how, when and why it came about, may therefore seem a fruitless endeavour, like attempting to catch soap bubbles, particularly because of the absence of medieval discussions on what a nation might be.

The challenge therefore remains to examine concepts of groups that are perceived as being of common descent and bound to a certain territory, without succumbing to the pitfalls of self-referentiality by identifying factors that neatly fit into concepts of the modern nation. Utterances of stereotyping the rethnic Other might indeed occur outside the nation-state, leaving us with the question what such rethnicity without groups entails. ${ }^{11}$ In that light, ethnic identity formation should be viewed as an ongoing process that engages with social reality and at the same time shapes it, constantly redefining what a nation itself might be.

In recent scholarship, attention has shifted to thinking about the relationship between the body and categories of ethnicity. This is a fruitful approach, in view of the fact that the body is the only given constant in ethnicity, and a nexus for three pertinent elements related to the concept of nationhood. ${ }^{12}$ First, the generic fact applies that the sum of bodies makes up nations, whose fluid or more fixed boundaries are drawn based on biological, cultural, religious or legal definitions, or a combination thereof (and in modernity mapped in the census). Second, the body may (although not necessarily) be viewed as the historical product of biological descent, encapsulated in origin myths and recalled in the collective memory in narratives, rituals, and artefacts; and the demise of the body - dying for the nation - viewed as a sacrifice for the future of the nation. ${ }^{13}$ Thirdly, the body's materiality - skin and hair colour, physical build and accompanying cultural artefacts - may serve as a marker for a sense of 'natural membership', together with its perceived national 'character' and mental characteristics (identified in later periods as Volksgeist or identity), which are shaped in part by its culture and collective memory. ${ }^{14}$

Approaches in order to understand this correlation between the body and the nation or ethnic group, may involve looking at word clusters attached to the words gentes or nationes, and examining the concepts grafted onto these groups of bodies of perceived common descent. What are the ontological meanings attached to these bodies, within a configuration of other factors such as the application of common law, geographical boundaries, the presence of communication networks, events such as warfare, inter-relational contacts, and processes such as that of bureaucratization? Are these clustered bodies for instance considered as inherently bound by a certain physicality (skin colour); tied to a certain territory (birth rights); to certain rights and duties (later bureaucratically encapsulated in the passport)? And how does

13 For origin myths, see for instance Eley, Myth of Trojan Descent and Perceptions of National Identity; Reynolds, Medieval Origines Gentium; Garber, Trojaner - Römer - Franken - Deutsche; Graus, Troja und die trojanische Herkunftssage; Hoppenbrouwers, Dynamics of National Identity. For the idea of dying for the patria in the later Middle Ages, see Post, Two Notes on Nationalism in the Middle Ages, 288-291; Kantorowicz, The King's Two Bodies, 247; Guenée, States and Rulers, 54; and Hirschi, Origins of Nationalism. See also Braude, The Sons of Noah. For collective Frankish memory, Gabriele, Empire of Memory.

14 For skin colour see Van der Lugt, La peau noire. 
the individual body stand as a pars pro toto for the whole nation, as an ethnotype? Such an approach might enter into a fruitful alliance with the field of ethnosymbolism, that regards the central components of ethnic and national phenomena as both sociocultural and symbolic, i.e. language, dress, emblems, rituals, artefacts, consisting in memories, myths, values and traditions ${ }^{15}{ }^{15}$ Accordingly, distinctive clusters of such symbolic components are said to delineate and guard the boundaries of ethnic groups. Myth-symbol complexes are thereby both constitutive, helping to structure an ethnic group's social relations and cultural institutions, and subjective, appealing to members' perceptions and beliefs. In this light, Smith has advocated focusing on processes wherein an 'ethnic past‘, encapsulated in myths, symbols, cultural traditions and values, is appropriated into new contexts on both the individual and communal level. Thus, instead of searching for the ethnic origins of nations in the past, the emic ethno-symbolic approach looks at how people defined and perceived themselves through their myths and symbols ('doing ethnicity), and how these were employed throughout various periods, in relation to politics and religious ideologies, and economic, cultural and social developments.

Such an approach also stretches to the body in its manifestation as an rethnotyper, and in particular to the conceptual constitutive and subjective typology of mental and physical traits ascribed to ethnic group members within various different religious, social and political contexts. Looking at the contexts and beliefs underlying the employment of these ethnic character types may thus help us firstly to understand the saliency of ethnicity, and secondly to pinpoint instances where its potentiality was capitalized upon. From the twelfth century, the dissemination of medical Galenic thought and its impact on concepts of ethnicity and race are said to have spurned geographically determined, biological ethnotypes, such as the 'melancholy Jew $<{ }^{16}$ These types were later - for instance in a fourteenth-century treatise by John of Newhouse - medically theorized as ethnic-biological categories that were passed down through parental transmission. ${ }^{17}$ The idea of the ethnotype as a pars pro toto for the group was further ensconced in the concept of the body politic, where the monarch was sometimes considered the embodiment of the nation. ${ }^{18}$ A specific aspect of these ethnotypes - the topic of this paper - is the grafting onto the body of shared mental characteristics or rethnic character'. In the period discussed here, the ninth to the thirteenth century, we can thus identity a shift in the underlying meaning and context of shared characteristics attached to the body, which were viewed first as shaped by culture, religion and God's plan for humanity, but thereupon shifted, from the twelfth century onwards, to medically conceived categories based on humoral theory.

For my research on the concept of ethnic character and its employment in the later Middle Ages, I have identified over one hundred and fifty sources from the period 1100-1250 containing substantial comments on ethnic groups and their characteristics in Western Europe For late medieval impact of humoral theory on general thinking about ethnicity, see especially Biller, Proto-racial thought in medieval science, and Ziegler, Physiognomy, Science, and Proto-Racism.

17 See Weeda, The Fixed and the Fluent, and the references there.

18 For the concept of the body politic and humoral theory, see Kaye, History of Balance; Syros, Galenic Medicine and Social Stability; Shogimen, Treating the Body Politic. 
in this period. ${ }^{19}$ The sources range from historiographical texts, chansons de geste, and encyclopaedias, to letters, poetry and classroom textbooks on rhetoric. A dominant feature in these sources is the listing of ethnic characteristics in catalogues. It was possible to discern at least three developments pertaining to these catalogues. Firstly, that the early lists of ethnic characteristics, dating back to the tenth century, are embedded in a religious-eschatological context; secondly, that from the late eleventh century, as translations from Arabic into Latin on humoral and climate theory entered the Latin West, listed virtues and vices of ethnic groups are increasingly ensconced in medical-humoral climate theory; and thirdly, that from this period onwards stereotypes are no longer based primarily on images from classical antiquity, but instead are more attuned to contemporary life worlds. Accordingly, an ontological shift occurs in the perceived relationship between shared characteristics and the rethnic body<, from biblical-moral eschatological concepts of salvation and ideas about chosenness, to medicalized and territorialized concepts of ethnic groups.

\section{Monastic lists}

To date, research on early medieval ethnic catalogues is scant, with no substantial explanation offered for their sudden appearance in tenth-century manuscripts. ${ }^{20} \mathrm{I}$ have identified about 25 manuscripts containing various examples of such lists for the period of the tenth to the thirteenth century. ${ }^{21}$ Many of these lists are in manuscripts containing computus-material calculating time, and embedded in encyclopaedic texts concerning geographical information and historiography.

The ethnic virtues and vices enumerated in the lists, are the reaping of centuries of learned religious and historiographical tradition. ${ }^{22}$ Knowledge of the diversity of humanity was gathered partly from classical, secular traditions - the stereotypes in these lists often are, perhaps unwittingly, grounded on climate theory, attributing violence, lack of intelligence, and unbridled emotions to groups dwelling in the northern territories of Europe, and wisdom to southerners and easterners - and partly from biblical exegesis, focusing on the proclivity to sin and receptiveness to the Christian message. For example, two Anglo-Saxon manuscripts of the eleventh century list the following vices or virtues:

19 Weeda, Images of Ethnicity in Later Medieval Europe.

20 Although aware of these earlier lists, Stanzel, discussing the birth of catalogues of nations, remarked that it is not possible to trace how these catalogues first arose, and little order has been detected within the catalogues. See Stanzel, Nationalitätenschema in der Literatur. Such lists are also mentioned, without an explanation, in Meyvaert, Voicing National Antipathy, 747; Brühl, Deutschland, Frankreich, 274; Fichtenau, Gentiler und europäischer Horizont, 80; Bartlett, Medieval and Modern Concepts, 49. See also Kot, Old International Insults and Praises, 181-209, for the development of these catalogues in the late Middle Ages in Eastern Europe. Stanzel, Zur literarischen Imagologie, 20, remarks upon the relationship between medieval catalogues and virtues and vices, but only in very general terms. Jeay, Le commerce des mots, is a recent study of the rise of lists in medieval literature, but does not specifically address ethnic catalogues.

21 See Weeda, Images of Ethnicity in Later Medieval Europe, Appendices, for a list of these manuscripts.

22 Stanzel, Nationalitätenschema in der Literatur, 85, notes that stereotypes in early modernity were mostly drawn from an ethnographic-literary treasure store. I would however like to emphasize here the influence of biblical exegesis, whose commentators reinforced traditional stereotypes. 


\begin{tabular}{|l|l|}
\hline The wisdom of the Greeks & The victory of the Egyptians \\
\hline The envy of the Jews & The envy of the Jews \\
\hline The pride of the Romans & The wisdom of the Greeks \\
\hline The generosity of the Longobards & The cruelty of the Picts \\
\hline The sobriety of the Goths & The strength of the Romans \\
\hline The raising up of the Franks ${ }^{23}$ & The generosity of the Longobards \\
\hline The gluttony of the Gauls & The gluttony of the Gauls \\
\hline The wrath of the Britons & The pride or ferocity of the Franks \\
\hline The stupidity of the Saxons & The wrath of the Britons \\
\hline The passion of the Scots & The stupidity of the Saxons or Angles \\
\hline The cruelty of the Picts. ${ }^{24}$ & The passion of the Scots. ${ }^{25}$ \\
\hline
\end{tabular}

The listings here of the Franks' ferocity, the wrath of the Britons, the stupidity of the Saxons, etc., are commonplaces based upon the unfavourable opinion formed in Antiquity of northern peoples as harsh, headstrong, and fierce. ${ }^{26}$ The envy of the Jews, on the other hand, goes hand in hand with references to them from the Christian perspective of their 'stubborn rejection of Christ as the Messiah, an image prominent in many of the catalogues similar to the above examples. ${ }^{27}$ Several characterizations in the lists accordingly stem either directly from, or in exegetical commentaries upon, the Pauline letters in the New Testament - letters written to evangelize and spread the message of the Messiah's arrival upon earth and the incumbent heavenly kingdom. Thus, for example in his early medieval exegetical commentary on Paul's Epistle to Titus about the Galatians' purported character trait of foolishness (foolish, that is, for choosing the Mosaic Law above the Christian faith), Jerome comments that 'the Cretans are denoted as liars, the Galatians as stupid, and the Israelites as stiff-necked, or each province according to its own vicer. ${ }^{28}$ A monk subsequently condensed Jerome's

23 Whether elevatio refers to baptism, Christianization, enthronement, moral raising up or even self-elevation or arrogance is very difficult to ascertain.

24 British Library, MS Cotton Caligula A. XV f. 122 v.: Sapientia Grecorum. Invidia Judeorum. Superbia Romanorum. Largitas Longobardum. Sobrietas Gothorum. Elevatio Francorum. Gula Gallorum. Ira Brittonum. Stultitia Saxonum. Libido Scottorum. Crudelitas Pictorum. The manuscript further contains entries on medicine, the moon, stars and winds. The reference to the Picts may reflect the ethnic origin of the scribe.

25 MS Harley 3271 f. 6v.: Victoria Aegiptiorum. Invidia Judeorum. Sapientia Graecorum. Crudelitas Pictorum. Fortitudo Romanorum. Largitas Longobardorum. Gulla Gallorum. Superbia vel ferocitas Francorum. Ira Britanorum. Stulticia Saxonum vel Anglorum. Libido Hibernorum. A facsimile is printed in Hodgkin, History of the Anglo-Saxons II, plate 53, 388. The list is attached to the Tribal Hidage; cf. Anlezark, Understanding Numbers in London, 154-155, for the dating of the manuscript.

26 See Fraesdorff, Der barbarische Norden, 187-194.

27 The stiff-necked Jews is a reference to Exodus 32:9 and Deuteronomy 9:13, where the Israelites break the covenant by constructing a golden calf in the absence of Moses, while he is receiving the Ten Commandments on Mount Horeb. God's wrath threatens to destroy the idolators. In the twelfth century, Germans are sometimes also called stiff-necked, for instance in Suger, Gesta Ludovici Grossi x. Cf. Kirn, Frühzeit des Nationalgefühls, 46; Dümmler, Über den Furor Teutonicus, 120-121; Curta, Furor Teutonicus, 62-76.

28 Jerome, Commentariorum in epistolam ad Titum Liber unus, PL 26, col. 0574C: Quomodo autem vel Cretenses mendaces, et stulti Galatae, vel dura cervice Israel, vel unaquaeque provincia proprio vitio denotetur. See also Hrabanus Maurus, Enarrationes in epistolas Beati Pauli, PL 112, col. 0672A. 
exegesis in the catalogue 'The envy of the Jews, the astuteness of the Greeks' and inserted it in a tenth-century computus manuscript, which was again copied and expanded by the English theologian and philosopher Robert Grosseteste around $1230 .{ }^{29}$ The 'envy of the Jews equally runs through the New Testament and biblical exegesis and is, for example, evoked in a passage on Paul and Barnabas' preaching in Antioch, where their proselytizing success among non-Jewish audiences was said to incite 'envy among the Jews', the latter ridiculing the evangelists and displaying 'stubbornness' in their refusal to accept the Christian message. ${ }^{30}$ Jews, it was said, had failed to comprehend their own divinely prophesized destiny and therefore lived rin error that they should have readily been able to understand and rectify<. ${ }^{31}$

The lists themselves are in some cases supplemented with catalogues of the apostles and their geographical destinies spreading Christianity to the four corners of the world, and may be placed within an eschatological context. For upon the spread of Christendom to the utmost corners of the world, Christ was expected to return in the end days. This explains the prominent position of the 'envious Jews', who often head the lists, as Augustine had taught that Jews played a crucial role in humanity's salvation, as their repentance and conversion to Christianity were deemed incumbent to Christ's Second Coming. ${ }^{32}$ The ontology of characteristics here thus entails the proclivity to enact sinful or virtuous behaviour, placed within a temporal-geographical schema. ${ }^{33}$

Most of the early examples of these ethnic lists commence with the ancient peoples of the East: Greeks, Jews, Chaldeans, and Egyptians. Catalogues subsequently migrate towards Rome and finally westwards to the Franks, the Britons, the Saxons, and the Picts. ${ }^{34}$ As such, these lists can be placed on the patristic East-West axis of identity. Both in space (from East to West) and time the lists reflect the progression of knowledge and power, known as the translatio, and the spread of Christianity. ${ }^{35}$ They conclude with the ethnic groups pertinent to the scribes' own life worlds - Goths, Franks, Picts. This westward progression was related to a specific strain of medieval theology that expounded that throughout time events passed from East to West, where eventually God's realm would bring this sublunary world to its end. ${ }^{36}$ Humanity, thus, was created in the East - the location of Paradise on the mappae

29 In the tenth-century Einsiedeln Stiftsbibliothek MS 321 f. 136: Judei duri cervice et gravi corde Greci leves Cretenses mendaces Dalmate feroces Mauri vani Franci tumidi Athenienses ingeniosi Galate indociles, vecordes, tardiores ad sapientiam. Robert Grosseteste, Expositio in epistulam sancti Pauli ad Galatas iii 1, ed. MacEvoy: ut Cretenses mendaces, malae bestiae, uentres pigri; Mauri uani; Dalmatae feroces; Phrygae timidi; Athenienses ingeniosi; Graeci leues; Iudaei graues corde et dura ceruice. Cf. Meier, Catalogus codicum manu scriptorum qui in Bibliotheca Monasterii Einsidlensis, vol. 1, 292-294.

30 Acts 13:45. See Lewis, Tractatus adversus Judaeos in the Gulbenkian Apocalypse, 552, for apocalyptical images of Jewish obstinacy.

31 Chazan, Medieval Stereotypes and Modern Antisemitism, 11.

32 Cf. Augustine, De civitate Dei xvii 46 and xx 29 and Tractatos adversus Judaeos, PL 42, col. 51-67; Sermo 200, 2 in PL 38, col. 1030. See Lewis, Tractatus adversus Judaeos in the Gulbenkian Apocalypse, 544, note 4 for further references, and Richards, Sex, Dissidence and Damnation, 93; Blumenkranz, Augustin et les juifs, 225-241.

33 Foucault, Order of Things, xviii.

34 Howe, Old English Catalogue Poems, 24-25.

35 Krämer, Translatio imperii et studii; Gassman, Translatio studii.

36 MacKenzie, Westward Progression of History on Medieval Mappaemundi, 335-344; Edson, Medieval World View, 508. 
mundi - and would cease to exist when events reached the farthest boundaries of the West, whereupon the day of reckoning would dawn. ${ }^{37}$ In the twelfth century Hugh of St. Victor (c. 1096-1141), who taught at the Augustinian school of St. Victor in Paris, stated this clearly:

The order of space and time seems to be in almost complete correspondence. Therefore, divine providence's arrangement seems to have been that what was brought about at the beginning of time would also have been brought about in the East - at the beginning, so to speak, of the world as space - and then as time proceeded toward its end, the centre of events would have shifted to the West, so that we may recognize out of this that the world nears its end in time as the course of events has already reached the extremity of the world in space. ${ }^{38}$

Among some theologians, including Hugh of St. Victor, this apocalyptical concept of the world's termination in the West was additionally tied to the idea that this would be achieved when Christianity had reached the farthest reaches of the West, the British Isles and Spain. This westward progression of peoples throughout time echoes the eschatological prophesy in the Old Testament Book of Daniel. ${ }^{39}$

The virtues and vices listed in the catalogues reflect the willingness of peoples to embrace the Christian message and overcome any ethnic tendencies to fall into vice. Just as the apostles brought Christianity to the boundaries of the world, such as in the Old English poem The Fates of the Apostles, so the enduring vices of peoples, both ancient and contemporary, were thus viewed as agents of events past, present and future. ${ }^{40}$ As medieval peoples each were considered to fulfil their role within the temporal and spatial context of the past creation in the East and future Christianisation in the West, upon which the earth would end, these ethnic catalogues offered a rhetorical-ethical mnemonic device for pondering ethnic virtues and vices, God's designs for humanity, and the fleeting nature of the world as well as its hidden meanings. Searching through the 'pockets of memory' in their mind (to use Carruthers' terminology), and chewing on these images, monks were turning their minds to the specific roles of their ethnic communities vis-à-vis the fate of humanity, hoping to recognize sin through picturing the images of sinful peoples in their minds. ${ }^{41}$ In this sense, these lists were not so much about confronting the ethnic Other with its supposed fallacies, but rather meant for introspection, reviewing the virtues, vices and role of all nations in the history of mankind. Concurrently, the ethnic virtues and vices enumerated in the lists were not so much considered as hereditary physical characteristics, but rather as moral proclivities within the system of cardinal sins, shaped by time and space, yet subject to free will - for by controlling

37 See for the location of Paradise in the East, Scafi, Mapping Paradise.

38 Hugh of St. Victor, De Arca Noe morali iv 9, in Patrologia Latina 176 Col. 677D: Ordo autem loci, et ordo temporis fere per omnia secundum rerum gestarum seriem concurrere videntur, et ita per divinam providentiam videtur esse dispositum, ut quae in principio temporum gerebantur in Oriente, quasi in principio mundi gererentur, ac deinde ad finem profluente tempore usque ad Occidentem rerum summa descenderet, ut ex ipso agnoscamus appropinquare finem saeculi, quia rerum cursus jam attigit finem mundi; quoted from Edson, Medieval World View, 507-508.

39 Daniel 2:31-45, who speaks of the successive realms of gold, silver, bronze and iron.

40 Howe, Old English Catalogue Poems, 24. See also Lavezzo, Angels on the Edge of the World. For the relationship between territory and peoples in early medieval geography, Merrills, History and Geography in Late Antiquity.

41 Carruthers, Craft of Thought, 30-1, 136, 146. 
the passions of the soul, these sins could be overcome. ${ }^{42}$ Territorially, the location of the ethnic groups was related to the groups' roles in the biblical past and proselytizing present, rather than to any comtemporary political entity. In addition, in the eastern tradition, the lists sometimes enumerated various linguistic traits. ${ }^{43}$

Knowledge of the etymology of ethnic names offered an supplementary tool for understanding the ressencer of peoples and ultimately for understanding the Bible's hidden messages. ${ }^{44}$ As Howe explains, for the early medieval encyclopaedist Isidore of Seville 'a fact is the name or word because from it may be derived knowledge of the thing itself $4 .{ }^{45}$ Such knowledge was obtained through etymological deduction, 'a hermeneutical principle according to which knowledge of a given thing may be realized from an understanding of its name ${ }^{4}{ }^{46}$ According to Isidore, at the moment of creation Adam spoke 'true words' when assigning names to things; and if two words were similar, they must also somehow be inherently related, for names referred to the active lives and behaviour of their owners. ${ }^{47}$ Thus, in learned medieval encyclopaedic thought, ethnonyms - one of the six main attributes of an ethnic community according to Smith and viewed as pivotal to ethnic awareness - were believed to reflect a transcendental entity; by examining the form of a word, one might learn to understand the essence of the entity. ${ }^{48}$

\section{Medicine and rhetoric}

If in the tenth century ethnic characterizations should thus be interpreted ontologically as agents in providential history, where some ethnic groups perhaps presented themselves as 'chosen peoples ${ }^{49}$ from the twelfth century we see an ontological shift in which aspects of heredity, fed by medical theory, come to the fore. Ethnotypes now commence to be viewed as biological categories, wherein for example the Jews are presented as melancholy. The rhetoric of heredity is for instance present in a twelfth-century sermon by Raoul Ardent of Poitou,

42 Bloomfield, Seven Deadly Sins, 66. There is assuredly some relation to the cardinal sins, catalogued in the sixth century by Gregory the Great as vainglory, envy, wrath, sadness, avarice, gluttony and lust - all stemming from the sin of pride. In Nationalitätenschema in der Literatur, 87, Stanzel relates the early catalogues to the seven deadly sins.

43 In an Armenian text of the early eighth century, recorded (although not composed) by archbishop Stephen of Siunik, ten peoples and their speech characteristics are summed up. Borst, Turmbau von Babel, vol. 1, 282; de Lagarde, Agathangelos, 150-163. In the thirteenth century, this list was incorporated by the Armenian Wardan Areveltsi in his history of the world up to 1267. As de Lagarde, Agathangelos, 151, has remarked, in this list language is reflective of a group's putative character. The Greek language is soft-natured, the Latin strong, that of the Huns audacious, the Assyrian humble or suppliant, the Persian rich, the Alan friendly, the Goth pleasant, the Egyptian tongue guttural, the Indian twittering like birds, and the Armenian agreeable, attaining all the qualities of the other languages. De Lagarde conjectures that this list was probably put together in the fifth century by an inhabitant of the East Roman Empire.

44 Lozovsky, The Earth Is Our Book, 48.

45 Howe, Old English Catalogue Poems, 34.

46 Idem, 60; cf. De Bouard, Les encyclopédies médiévales, 286; Kästner, Der großmächtige Riese und Recke Teuton, 75-77. For a discussion of ethnic names, see Rübekeil, Völkernamen Europas, 1330-1343; Haubrichs, Veriloquium nominis, 231-256.

47 Friedman, Monstrous Races, 110.

48 Smith, National Identity, 21.

49 Smith, Chosen Peoples; Garrison, The Franks as the New Israel?; Murray, Bede and the Unchosen Race, Gabriele, The Chosen Peoples. 
in a homily on John 3, where he urges his audience 'to rise above the vice of his own people. If you are a Jew, take pains to rise above your innate disbelief. If you are from France, take pains to overcome your innate arrogance. If you are from Rome, take pains to overcome your innate avarice. ${ }^{50}$ As mentioned above, in the late Middle Ages, humoral and climate theory and the concept of the body politic likewise gained currency: envisaging city-states and kingdoms as a body, whose rulers, institutions, officials and social groups represented its limbs and organs. Accordingly, the ethnotype would evolve into a pars pro toto for city-states or monarchies, thereby gaining meaning as a benchmark for membership of a now more clearly embodied and delineated ethnic group (defined by, among others, body shape, hair and skin colour, and character), to be contrasted with the ethnic Other. Thus, in the late thirteenth century, discussions crop up about whether the French monarch should necessarily be born and sired in his perceived natural environment of Paris, as locality now had to dovetail with natural categories of ethnicity. ${ }^{51}$

In addition, at the end of the twelfth century, a number of fresh manuals on grammar appeared, such as Alexander of Villedieu's Doctrinale (1199) and Évrard (or Eberhard) of Béthune's Graecismus (1212), and in the field of poetry, Matthew of Vendôme's Art of Versification (early 1170s), Gervase of Melkley's Art of Versification (late twelfth century) and Geoffrey of Vinsauf's New Poetry (1200). These manuals explicitly prescribed how to apply ethnic images in order to create convincing literary types through description and invention, and were in themselves repositories of stereotypes, teaching their students to use commonplaces. They also reflect the territorialisation of the habitat of ethnic groups. The drawing of boundaries, although in these kinds of text by approximation, nonetheless shows an understanding that named groups displaying communal characteristics were perceived to inhabit specific territorial entities and were commonly recognized as such..$^{2}$ For example, in one of the most popular of medieval treatises on the art of poetry, the Poetria Nova (written circa 1208/1213), Geoffrey of Vinsauf advises to let territories stand for their peoples, embellished by the ethnic group's reputation:

Use the container for the contained, aptly employing either a noun or an adjective.

Apply the noun thus:

Tippling England; weaving Flanders; boastful Normandy.

Thus use the adjective:

The noisy forum; the silent cloister; the doleful prison; the happy house; the quiet night; the busy day. ${ }^{53}$

The tight relationship between territory and inhabitants is now expressed in explanations

50 Raoul Ardent, Homilia ii, 2 »In die Trinitatis«, PL 155, col. 1949C-D: Conemur unusquisque vitium populi sui superare. Si Judaeus es, stude Judaeis innatam incredulitatem superare. Si Gallus es, stude Gallis innatam superbiam superare. Si Romanus es, stude Romanis innatam avaritiam superare. Cf. Meyvaert, Rainaldus est malus scriptor Francigenus, 748. For concepts of heredity in the late Middle Ages, see Van der Lugt and De Miramon, L'hérédité entre Moyen Age et Époque modern.

51 Pierre Dubois, De recuperatione terrae sanctae.

52 For the rise of rhetorical manuals see Martin, Classicism and Style in Latin Literature, 538.

53 Geoffrey of Vinsauf, Poetria Nova vs. 1006-1017, ed. and trans. Gallo, 67-69: Rem vice contenti quae continet accipe, ponens / Verbum, vel fixum, vel mobile quodlibet, apte. / Insere sic fixum: Potatrix Angia; Textrix / Flandria; Jactatrix Normannia. Mobile nomen / Sic appone: Fora clamosa; Silentia claustra; / Luctisonus carcer; Domus exhilarate; Quieta / Nox; Operosa dies. 
of the metonymic figure of speech known as the continens pro contento, wherein a word is substituted by another on the grounds of a close connection. In some manuals, this form of metonymy is expounded using the example of a territory - 'the container - replete with an ethnic group - 'the contained،. Thus, in a thirteenth-century rhetorical poem from the monastery of Clairmarais in Saint Omer, the container - Flanders - >flowers with delights as does France with teaching (with Paris considered the location of the translatio studii). ${ }^{54}$ The advice is elucidated with the explanation: 'Flanders stands for the Flemish, France for the French ${ }^{55}$ The same development can be discerned in the visual depiction of the world in mappae mundi, for example in the Beatus map drawn circa 1065 in the abbey of Saint-Sever in southern France, where Gascony, Poitiers and now Aquitaine are visualized as separate entities. ${ }^{56}$

Partly as a result of this new and heightened attention to composition, ethnic characterizations increasingly entered verse composition either praising and blaming, debating (in so-called Streitgedichte, battle poems) or satirizing peoples. In Matthew of Vendôme's advice on depicting character derived from natio and patria - the latter making reference to the location of origin - he engages with the topical attack on Roman avarice: 'Rome thirsts for gold, loves those who give; without the dative, Rome refuses to favour the accusative. ${ }^{57}$ Complaints against Rome were highly popular in contemporary parody and satire, first develolping in the eleventh century as invective against the practice of simony and the power of money at the Roman curia, whereto the world's riches flowed..$^{8}$ The Church, whose institutions were becoming more powerful, thereby remained the reference point for the diversity of the regions, and their relative wealth. As in the tenth century lists, ethnicity is still conceived as related to local produce, which is also attested to in the collections of 'proverbial knowledge from this period, compiled as material out of which to draw readymade and convincing typologies..$^{59}$ However, now the context no longer is salvation history, but the taxation of territories by the institution of the Church. In the early part of the twelfth century, an anonymous cleric, perhaps from Lotharingia or Gallia, enumerates the natural resources of the world's regions, ranging from east to west, in the anti-Roman invective 'The Cunning People of Romer ${ }^{60}$ Moving from east to west, Rome, the pinnacle of nations, now hankers after the riches of the world, worshiping the gold of Arabia, the ornate robes of Greece, the

54 Lusignan, L'Université de Paris comme composante de l'identité du royaume de France.

55 In Saint Omer MS. 115 f. 53B. Printed in Fierville, Notice et extraits des manuscripts de la bibliothèque de SaintOmer 106, no. 40: Flandria deliciis [...] Flandria designat Flandrenses, Gallia Gallos.

56 Baumgärtner, Die Welt im kartographischen Blick, 540. Cf. Englisch, Ordo Orbis Terrae, 336-364.

57 Matthew of Vendôme, Ars versificatoria i 82, ed. Munari, 98-99: Aurum, Roma sitit, dantes amat, absque dativo, / Accusativis Roma favere negat.

58 Benzinger, Invectiva in Romam, 74-76; Lehmann, Parodie im Mittelalter, 51-52.

59 For instance, an early Old French collection of proverbs, known under the title 'Dit de l'Apostoile‘, contained in a thirteenth-century manuscript, served this very purpose and is thus replete with lists characterizing peoples, professions and regions of France, including types of wines and cheeses, such as fromage de Brie. See >Proverbes et dictons populaires‘, printed in Prompsault, Discours sur les publications littéraires du moyen-age, 114-140.

60 Benzinger, Invectiva in Romam, 111-113; Yunck, Lineage of Lady Mead, 80-81; Lehmann, Parodie im Mittelalter, $25-68$. 
ivory and jewels of India, the delightful produce of France, the silver and gold of England, the milk and butter of Flanders, and the stallion and mare mules of Burgundy. 'Rome devours them all completely, with no worthiness left at all. ${ }^{61}$

These lists could be read out loud to international student communities, feeding off and shaping social relations within them. The Italian master Boncompagno da Signa, for example, used lists of ethnic characteristics in his lectures on rhetoric in early thirteenth-century Bologna. ${ }^{62}$ This also gives context to Jacques de Vitry's famous and oft-quoted remark that students in Paris engaged in verbal and physical altercations, deriding the English as drunks, the Brabanders as rapists and the Flemish as butter balls. ${ }^{63}$ Although in part a continuation of the older monastic lists, the context of the characteristics is now in part political; Boncompagno for instance repeatedly refers in his lists to Italian libertas. The bodily characteristics of the French crusaders, likewise, are extolled as ideal characteristics of fighters who, as protectors of the Church, might stake a claim to yielding imperium.${ }^{64}$ All of these examples are evidence of a consciousness that individuals were affiliated to groups that shared certain characteristics and that were linked to a territory or to a past that now might take on political significance.

Examining the specific context and employment of ethnotypes, encapsulating various aspects of the ethnic body in relation to space, time, law, language, religion and politics, may thus help shed light on concepts of how nations developed. We can identify a shift from thinking about ethnic virtues and vices in relationship to a providential history of mankind to thinking of ethnotypes as a hereditary pars pro toto for increasingly territorialized ethnic communities (sometimes represented by the monarch). How these concepts of the body were related to other processes, including bureaucratization, the development of a written culture, the materialization of parliaments, and the development of concepts of public welfare and political thought will require research from multifarious perspectives in which the situational aspects and processes are constantly re-evaluated.

61 Gens Romanorum subdola antiqua colit hydola vs. 6-14, in Libelli de lite imperatorum et pontificum saeculis xi et xii conscripti, ed. Dümmler et al., iii, 705-706: Roma deglutit penitus, / Digna perire funditus. Cf. Mone, Anzeiger für Künde der teutschen Vorzeit 8 (1839), 597; Lehmann, Die Parodie im Mittelalter, 52.

62 For instance in Boncompagno da Signa, Palma 45, Quid sit clausula et ex quot distinctionibus consistere possit, ed. Sutter, Aus Leben und Schriften des Magisters Boncompagno, 122-123.

63 Jacques de Vitry, Historia Occidentalis, ed. Hinnebusch, 92.

64 Weeda, Violence, Control, Prophecy and Power. 


\section{References}

\section{Primary sources}

Augustine, Sermo 200, ed. Jacques-Paul Migne, PL 38.

Augustine, Tractatos adversus Judaeos, ed. Jacques-Paul Migne, PL 42.

Boncompagno da Signa, Palma, ed. Carl Sutter, Aus Leben und Schriften des Magisters Boncompagno (Freiburg i. B., 1894).

Chroniques Asturiennes, ed. Yves Bonnaz (Paris, 1987).

Chronica minora saec. iv. v. vi. vii, ed. Theodor Mommsen, MGH Auctores Antiquissimi 11 (Berlin, 1894) 389-390.

Libelli de lite imperatorum et pontificum saeculis xi et xii conscripti ed. Ernst Dümmler et al. (Hannover, 1897).

Geoffrey of Vinsauf, Poetria Nova, ed. and trans. Ernest Gallo, The Poetria Nova and its Sources in Early Rhetorical Doctrine (The Hague, 1971).

Hrabanus Maurus, Enarrationes in epistolas Beati Pauli, ed. Jacques-Paul Migne, PL 112.

Hugh of St Victor, De arca Noe morali Libri, ed. Jacques-Paul Migne, PL 176.

Jacques de Vitry, Historia Occidentalis, ed. John Frederick Hinnebusch, The Historia Occidentalis of Jacques de Vitry: A Critical Edition (Fribourg, 1972).

Jerome, Commentariorum in epistolam ad Titum Liber unus, ed. Jacques-Paul Migne, PL 26.

Matthew of Vendôme, Ars versificatoria, ed. Franco Munari, Mathei Vindocinensis opera Franco Munari (Rome, 1988), trans. Roger P. Parr, Ars versificatoria (Milwaukee, 1981).

'Proverbes et dictons populaires', ed. Jean-Henri-Romain Prompsault, Discours sur les publications littéraires du moyen-age (Paris, 1835) 114-140.

Raoul Ardent, Homilia, ed. Jacques-Paul Migne, PL 155.

Robert Grosseteste, Expositio in epistulam sancti Pauli ad Galatas, ed. James MacEvoy, CC CM 130 (Turnhout, 1995).

Suger, Gesta Ludovici Grossi, ed. and trans. Richard Cusimano and John Moorhead, The Deeds of Louis the Fat (Washington DC, 1992).

\section{Secondary Literature}

Anlezark, Daniel, Understanding Numbers in London, The British Library, Harley 3271, Anglo-Saxon England 39 (2009) 137-155.

Bauchau, Bénédicte, Science et racisme: les juifs, la lèpre et la peste, Stanford French Review 13 (1989) 21-35.

Bartlett, Robert, Medieval and Modern Concepts of Race and Ethnicity, Journal of Medieval and Early Modern Studies 31/1 (2001) 39-56.

Bartlett, Robert, The Making of Europe: Conquest, Colonization and Cultural Change, 950-1350 (London, 1994).

Baumgärtner, Ingrid, Die Welt im kartographischen Blick: Zur Veränderkeit mittelalterlicher Weltkarten am Beispiel der Beatustradition vom 10. bis 13. Jahrhundert, in: Wilfried Ehbrecht, Angelika Lampen, Franz-Joseph Post and Mechtild Siekmann (eds.), Der weite Blick des Historikers: Einsichten in Kultur-, Landes- und Stadtgeschichte. Peter Johanek zum 65. Geburtstag (Köln, 2002) 527-549.

Benzinger, Josef, Invectiva in Romam. Romkritik im Mittelalter vom 9. bis zum 12. Jahrhundert, Matthiesen Verlag (Lübeck, 1968). 
Biller, Peter, A `Scientific`View of Jews from Paris around 1300, Gli Ebrei el le scienze, Micrologus 9 (2001) 137-168.

Biller, Peter, Proto-Racial thought in Medieval Science, in: Miriam Eliav-Feldon, Benjamin Isaac and Jospeh Ziegler (eds.), The Origins of Racism in the West (Cambridge, 2009) 157180.

Blaicher, Günther, Zur Entstehung und Verbreitung nationaler Stereotypen in und über England, Deutsche Vierteljahrsschrift für Literaturwissenschaft und Geistesgeschichte 51 (1977) 549-574.

Bloomfield, Morton W., The Seven Deadly Sins: an Introduction to the History of a Religious Concept (Ann Arbor, 1967).

Blumenkranz, Bernhard, Augustin et les juifs; Augustin et le judaisme, Recherches augustiniennes 1 (1958) 225-241.

Borst, Arno, Der Turmbau von Babel. Geschichte der Meinungen über Ursprung und Vielfalt der Sprachen und Völker, 6 vols. (Stuttgart, 1957-1963).

Bouard, Michel de, Les encyclopédies médiévales sur 'La connaissance de la nature et du monder, Revue des questions historiques 116 (1930) 258-304

Braude, Benjamin, The Sons of Noah and the Construction of Ethnic and Geographical Identities in the Medieval and Early Modern Periods, The William and Mary Quarterly: A Magazine of Early American History 54 (1997) 103-142.

Brubaker, Rogers, Ethnicity without Groups (Cambridge, Mass., 2006).

Brühl, Carlrichard, Deutschland, Frankreich. Die Geburt zweier Völker (Cologne, 1990).

Burnam, John M., Miscellanea Hispanica, Modern Philology 12/3 (1914) 165-170.

Burton, John W., Culture and the Human Body: an Anthropological Perspective (Long Grove, 2001).

Carruthers, Mary, The Craft of Thought: Meditation, Rhetoric, and the Making of Images, 40o1200 (Cambridge, 2003).

Chazan, Robert L., Medieval Stereotypes and Modern Antisemitism (Berkeley, 1997).

Clanchy, Michael T., England and its Rulers, 1066-1272 (3rd edition) (Malden, 2006).

Coulton, George G., Nationalism in the Middle Ages, Cambridge Historical Journal 5/1 (1935) 15-40.

Curta, Florin, Furor Teutonicus: A Note on Ethnic Stereotypes in Suger's Deeds of Louis the Fat, The Haskins Society Journal: Studies in Medieval History 16 (2005) 62-76.

Davies, Robert Rees, Presidential Address: the People of Britain and Ireland 1100-1400. I. Identities, Transactions of the Royal Historical Society 4 (1994) 1-20.

Davies, Robert Rees, Presidential Address: the Peoples of Britain and Ireland 1100-1400. II. Names, Boundaries and Regnal Solidarities, Transactions of the Royal Historical Society 5 (1995) 1-20.

Davies, Robert Rees, Presidential Address: the Peoples of Britain and Ireland 1100-1400. III. Laws and Customs, Transactions of the Royal Historical Society 6 (1996) 1-23.

Davies, Robert Rees, Presidential Address: the Peoples of Britain and Ireland 1100-1400. IV. Language and Historical Mythology, Transactions of the Royal Historical Society 7 (1997) 1-24.

Dümmler, Ernst, Über den Furor Teutonicus, Sitzungsberichte der Königlich Preussische Akademie der Wissenschaften zu Berlin 9 (1897) 112-126.

Edson, Evelyn, The Medieval World View: Contemplating the Mappamundi, History Compass 8/6 (2010) 503-517.

Ehlers, Joachim, Die Entstehung des deutschen Reiches (München, 1994). 
Ehlers, Joachim, Elemente mittelalterlicher Nationsbildung in Frankreich (10.-13. Jahrhundert) Historische Zeitschrift 231/3 (1980) 565-587.

Eliav-Feldon, Miriam, Isaac, Benjamin and Ziegler, Joseph, The Origins of Racism in the West (Cambridge, 2009).

Eley, Penny, The Myth of Trojan Descent and Perceptions of National Identity: the Case of 'Eneas' and the 'Roman de Troie', Nottingham Medieval Studies 35 (1991) 27-40.

Englisch, Brigitte, Ordo Orbis Terrae. Die Weltsicht in den Mappae mundi des frühen und hohen Mittelalters, Orbis mediaevalis. Vorstellungswelten des Mittelalters 3 (Berlin, 2002).

Fichtenau, Heinrich, Gentiler und europäischer Horizont an der Schwelle des ersten Jahrtausends, Römische Historische Mitteilungen (1981) 80-97.

Fierville, Charles M., Notice et extraits des manuscripts de la bibliothèque de Saint-Omer, Notices et extraits des manuscrits de la Bibliothèque Nationale 31 (1884) 49-156.

Foucault, Michel, The Order of Things: An Archaeology of the Human Sciences (New York, 1994).

Fraesdorff, David, Der barbarische Norden. Vorstellungen und Fremdheitskategorien bei Rimbert, Thietmar von Merseburg, Adam von Bremen und Helmold von Bosau, Orbis mediaevalis. Vorstellungswelten des Mittelalters 5 (Berlin, 2005).

Friedman, John B., The Monstrous Races in Medieval Art and Thought (reprint) (New York, 2000).

Gabriele, Matthew, An Empire of Memory: the Legend of Charlemagne, the Franks, and Jerusalem before the First Crusade (Oxford, 2011).

Gabriele, Matthew, The Chosen Peoples of the Eleventh and Twenty-First Centuries, Relegere: Studies in Religion and Perception 2/2 (2012) 281-290.

Garber, Jörn, Trojaner - Römer - Franken - Deutsche. 'Nationale` Abstammungstheorien im Vorfeld der Nationalstaatsbildung, in: Klaus Garber (ed.), Nation und Literatur im Europa der Frühen Neuzeit. Akten des I. Internationalen Osnabrücker Kongresses zur Kulturgeschichte der frühen Neuzeit (Tübingen, 1989) 108-163.

Garrison, Mary, The Franks as the New Israel? Education for an Identity from Pippin to Charlemagne, in: Yitzak Hen and Matthew Innes (eds.), The Uses of the Past in the Early Middle Ages (Cambridge, 2000) 114-161.

Gassman, David L., Translatio studii: a Study of Intellectual History in the Thirteenth Century, 2 vols. (Ann Arbor, 1973).

Graus, František, Troja und die trojanische Herkunftssage im Mittelalter, in: Willi Erzgräber (ed.), Kontinuität und Transformation der Antike im Mittelalter, Veröffentlichung der Kongreßakten zum Freiburger Symposion des Mediävistenverbandes (Sigmaringen, 1989) 25-43.

Guenée, Bernard, States and Rulers in Later Medieval Europe (Oxford, 1985).

Haubrichs, Wolfgang, Veriloquium nominis. Zur Namensexegese im frühen Mittelalter, Verbum et signum: Beiträge zur mediävistischen Bedeutungsforschung 1(1975) 231-266.

Hirschi, Caspar, The Origins of Nationalism: an Alternative History from Ancient Rome to Early Modern Germany (Cambridge, 2012).

Robert H. Hodgkin, History of the Anglo-Saxons II (Oxford, 1952).

Hoppenbrouwers, Peter C. M., The Dynamics of National Identity in the Later Middle Ages, in: Robert Stein and Judith S. Pollmann (eds.), Networks, Regions and Nations: Shaping Identities in the Low Countries, 1300-1650 (Leiden, 2010) 19-42.

Howe, Nicholas, The Old English Catalogue Poems (Copenhagen, 1985).

Jeay, Madeleine, Le commerce des mots: L'usage des listes dans la littérature medieval (Geneva, 2006). 
Johnson, Willis, The Myth of Jewish Male Menses, Journal of Medieval History 24/3 (1998) 273-295.

Kantorowicz, Ernst H., The King's Two Bodies: a Study in Medieval Political Theology (Princeton, 1957).

Kästner, Hannes, Der grossmächtige Riese und Recke Teuton: Etymologische Spurensuche nach dem Urvater der Deutschen am Ende des Mittelalters, Zeitschrift für deutsche Philologie 110 (1991) 68-97.

Kaye, Joel, A History of Balance 1250-1375: the Emergence of a New Model of Equilibrium and its Impact on Thought (Cambridge, 2014).

Kirn, Paul, Aus der Frühzeit des Nationalgefühls. Studien zur deutschen und französischen Geschichte sowie zu den Nationalitätenkämpfen auf der Britischen Inseln (Leipzig, 1943).

Koht, Halvdan, The Dawn of Nationalism in Europe, The American Historical Review 52/2 (1947) 265-280.

Kot, Stanislaw, Old International Insults and Praises: I. The Medieval Period (Freeport, NY, 1971).

Krämer, Ulrike, Translatio imperii et studii. Zum Geschichts- und Kulturverständnis in der französischen Literatur des Mittelalters und der frühen Neuzeit (Bonn, 1996).

Lagarde, Paul de, Agathangelos, Abhandlungen der Königlichen Gesellschaft der Wissenschaften zu Göttingen, Historisch-Philologische Klasse 35 (1889) 150-163.

Lavezzo, Kathy, Angels on the Edge of the World: Geography, Literature and English Community 1000-1534 (Ithaca, New York, 2006).

Lehmann, Paul J.G., Die Parodie im Mittelalter (reprint) (Stuttgart, 1963).

Lewis, Suzanne, Tractatus adversus Judaeos in the Gulbenkian Apocalypse, The Art Bulletin 68/4 (1986) 543-566.

Lozovsky, Natalia, »The Earth Is Our Book«: Geographical Knowledge in the Latin West ca. 40o1000 (Ann Arbor, 2000).

Lugt, Maaike van der and Miramon, Charles de (eds.), L'hérédité entre Moyen Âge et Époque moderne: Perspectives historiques (Florence, 2008).

Lugt, Maaike van der, La peau noire dans le science médiévale, Micrologus: natura, scienze e società medievali 13 (2005) 439-475.

Lusignan, Serge, L'Université de Paris comme composante de l'identité du royaume de France: étude sur le thème de la translatio studii, in: Rainer Babel and Jean Marie Moeglin (eds.), Identité régionale et conscience nationale en France et en Allemagne du Moyen Âge à l'époque moderne, Beihefte der Francia (Sigmaringen, 1997) 59-72.

MacKenzie, Stephen, The Westward Progression of History on Medieval Mappaemundi: An Investigation of the Evidence, in: Paul D. A. Harvey (ed.), The Hereford World Map. Medieval World Maps and their Context (London, 2006) 335-344.

Martin, Janet, Classicism and Style in Latin Literature, in: Robert L. Benson, Giles Constable and Carol D. Lanham (eds.), Renaissance and Renewal in the Twelfth Century (Cambridge Mass., 1982) 537-568.

Meier, Gabriel, Catalogus codicum manu scriptorum qui in Bibliotheca Monasterii Einsidlensis O.S.B. servantur (Einsiedeln, 1899).

Merrills, Andrew H., History and Geography in Late Antiquity (Cambridge, 2005).

Meyvaert, Paul, Rainaldus est malus scriptor Francigenus: Voicing National Antipathy in the Middle Ages, Speculum: A Journal of Medieval Studies 66/4 (1991) 743-763.

Mohr, Walter, Zur Frage des Nationalismus im Mittelalter, Annales Universitatis Saraviensis: Philosophie - Lettres 2 (1953) 106-116. 
Murray, Alexander, Bede and the Unchosen Race, in: Huw Pryce and John Watts (eds.), Power and Identity in the Middle Ages. Essays in Memory of Rees Davies (Oxford, 2007) 52-67.

Omont, Henri, Vices et vertus des différents peuples, Bibliothèque de l'Ecole des Chartres 45/1 (1884) 580-581.

Post, Gaines, Two Notes on Nationalism in the Middle Ages, Traditio 9 (1953) 281-320.

Reynolds, Susan, Medieval Origines Gentium and the Community of the Realm, History 68 (1983) 375-390.

Richards, Jeffrey, Sex, Dissidence and Damnation: Minority Groups in the Middle Ages (New York, 1990).

Rübekeil, Ludwig, Völkernamen Europas, in: Ernst Eichler, Gerold Hilty, Heinrich Löffler, Hugo Steger and Ladislav Zgusta (eds.), Name Studies: an International Handbook of Onomastics (Berlin, 1996) 1330-1343.

Scafi, Alessandro, Mapping Paradise: a History of Heaven and Earth (London, 2006).

Schmugge, Ludwig, Über »nationale«Vorurteile im Mittelalter, Deutsches Archiv für Erforschung des Mittelalters 38 (1982) 439-459.

Shogimen, Takashi, Treating the Body Politic: The Medical Metaphor of Political Rule in Late Medieval Europe and Tokugawa Japan, The Review of Politics 70/1 (2008) 77-104.

Smith, Anthony D., Ethno-Symbolism and Nationalism: A Cultural Approach (London, 2009).

Smith, Anthony D., National Identity (London, 1991).

Smith, Anthony D., Chosen Peoples (Oxford, 2003).

Stanzel, Franz K., Das Nationalitätenschema in der Literatur und seine Entstehung zu Beginn der Neuzeit, in: Günther Blaicher (ed.), Erstarrtes Denken. Studien zu Klischee, Stereotyp und Vorurteil in englischsprachiger Literatur (Tübingen, 1987) 84-96.

Stanzel, Franz K., Zur literarischen Imagologie. Eine Einführung, in: Franz K. Stanzel, Ingomar Weiler and Waldemar Zacharasiewicz (eds.), Europäischer Völkerspiegel: Imagologischethnographische Studien zu den Völkertafeln des frühen 18. Jahrhunderts (Heidelberg, 1999) 9-39.

Syros, V., Galenic Medicine and Social Stability in Early Modern Florence and the Islamic Empires, Journal of Early Modern History 17 (2013) 161-213.

Tipton, Leon C. (ed.), Nationalism in the Middle Ages (New York, 1972).

Weeda, Claire V., Ethnic Identification and Stereotypes in Later Medieval Western Europe, History Compass 12/7 (2014) 586-606.

Weeda, Claire V., Ethnic Stereotyping in Twelfth-Century Paris, in: Meredith Cohen and Justine Firnhaber-Baker (eds.), Difference and Identity in Francia and Medieval France (Farnham and Burlington VT, 2010) 115-135.

Weeda, Claire V., Images of Ethnicity in Later Medieval Europe. Unpublished PhD thesis (University of Amsterdam, 2012).

Weeda, Claire V., The Fixed and the Fluent: Geographical Determinism, Ethnicity and Religion c. 1100-1300 CE, in: Rebecca Futo Kennedy and Molly Jones-Lewis (eds.), Routledge Companion to Identity and the Environment in the Ancient and Medieval Worlds (London, 2015). Retrieved on 8 June 2017: www.routledgehandbooks.com/ doi/10.4324/9781315686622.ch6.

Weeda, Claire V., Violence, Control, Prophecy and Power in Twelfth-Century France and Germany, in: Janet Nelson and Damien Kempf (eds.), Reading the Bible in the Middle Ages (London, 2015) 147-166. 
Wright, Thomas and Halliwell-Phillips, James O. (eds.), Reliquiae antiquae: Scraps from Ancient Manuscripts, Illustrating Chiefly Early English Literature and the English Language, 2 vols. (New York, 1966).

Yunck, John A., The Lineage of Lady Mead: the Development of Medieval Venality Satire (Notre Dame, 1963).

Ziegler, Joseph, Physiognomy, Science, and Proto-Racism 1200-1500, in Miriam EliavFeldon, Benjamin Isaac and Joseph Ziegler (eds.), The Origins of Racism in the West (Cambridge, 2009) 181-199 